\title{
Lochkovian conodonts from Podolia, Ukraine, and their stratigraphic significance
}

\author{
Daniel Drygant and Hubert Szaniawski \\ Acta Palaeontologica Polonica 57 (4), 2012: 833-861 doi: http://dx.doi.org/10.4202/app.2012.0124
}

In the Podolian Dniester Basin (southwestern Ukraine) the Lower Devonian marine deposits are represented by about $530 \mathrm{~m}$ thick continuous sequence of interlaminated carbonate and schale outcrops at several localities. Conodonts occur in most of the carbonate layers of the whole Lochkovian but are not abundant and their ramiform elements are mostly broken or lacking. Therefore, only the pectiniform, Pa elements of twenty five stratigraphically important conodont species occurring in the region are discussed and two new species, Caudicriodus schoenlaubi and Pandorinellina? parva are proposed. The hypothetical phyletic relationships within the main representatives of the icriodontid and spathognathodontid genera, Caudicriodus, Zieglerodina, and Pandorinellina? are traced. Comparison of the previously published and newly obtained data revealed discrepancies in the hitherto used interpretation of some of the conodont taxa and their stratigraphic ranges. Contrary to the earlier reports, Caudicriodus postwoschmidti does not occur in the lower Lochkovian but only in the middle part of the Chortkiv Formation, high above the Monograptus uniformis Zone. Based on new material and verification of the previous determinations, a modified scheme of the Lochkovian conodont zonation in Podolia is proposed. Conodont zones: Caudicriodus hesperius, C. transiens, C. postwoschmidti, C. serus, and ?Caudicriodus steinachensis are distinguished. The zones are correlated with conodont zonations in other regions-Barrandian, Cantabrian Mountains, Pyrenees, and Nevada. Biostratigraphy of the Siluro-Devonian transition and Lochkovian is integrated with the carbon isotope stratigraphy.

Key words: Conodonta, evolution, stratigraphy, Devonian, Lochkovian, Podolia, Ukraine

Daniel Drygant [drygant@museum.lviv.net], State Museum of Natural History, National Academy of Sciences of Ukraine, Teatralna 18, Lviv 79008, Ukraine; Hubert Szaniawski [szaniaw@twarda.pan.pl], Institute of Palaeobiology, Polish Academy of Sciences, Twarda 51/55, 00-818 Warszawa, Poland. 
This is an open-access article distributed under the terms of the Creative Commons

Attribution License (for details please see creativecommons.org), which permits unrestricted use, distribution, and reproduction in any medium, provided the original author and source are credited.

Forif Full text $(1,854.7 \mathrm{kB})$ 